\title{
Study on the Influencing Factors of Teaching Effect of University Teachers during the Period of the Epidemic
}

\author{
Rong Chen \\ Department of Physics, Nanchang Normal University, Nanchang, China \\ Email:xinseafank@163.com
}

How to cite this paper: Chen, R. (2020) Study on the Influencing Factors of Teaching Effect of University Teachers during the Period of the Epidemic. Open Access Library Journal, 7: e6604. https://doi.org/10.4236/oalib.1106604

Received: July 12, 2020

Accepted: August 4, 2020

Published: August 7, 2020

Copyright $\odot 2020$ by author(s) and Open Access Library Inc.

This work is licensed under the Creative

Commons Attribution International

License (CC BY 4.0).

http://creativecommons.org/licenses/by/4.0/

\section{(c) (i) Open Access}

\begin{abstract}
With the spread of the epidemic, the problem of online teaching has become one of the focuses of the whole society. As the organizer of online teaching, the teaching effect of university teachers should be paid more attention to. This study takes university teachers as the research object, understands the current situation of online teaching, expounds the influencing factors of teaching effect, and also analyzes the correlation among teachers' adaptability, teachers' attitude and teaching effect. There is a positive correlation among teachers' adaptability, teachers' attitude and teaching effect. The prediction model of the relationship is constructed between teachers' attitude and teaching effect.
\end{abstract}

\section{Subject Areas}

Education

\section{Keywords}

Epidemic, Online Teaching, Prediction Model

\section{Introduction}

During the epidemic, in order to stop the spread of the epidemic to the campus and ensure the life safety and health of teachers and students, the Ministry of education of China on January 29, 2020 requested that the spring semester of 2020 should be postponed. Students stay at home, do not go out, do not participate in parties, and do not hold gathering activities. In order to prevent students from delaying their studies due to the epidemic situation, the Ministry of Education proposed that all kinds of schools should use the network platform to im- 
plement the "class suspension without suspension". During the period of epidemic prevention and control, carrying out network teaching work is an emergency action to deal with epidemic situation and ensure "suspension without suspension". Carry out network teaching activities, try to reduce the negative impact of the epidemic on the normal school teaching order. Many online teaching platforms are difficult to cope with the university network teaching; live broadcast network often appears blocked. College students across the country have the same ideological and political course on epidemic prevention and control, and also many people can't even enter the platform. In the sudden network teaching, some teachers are unprepared for the pure network teaching. The teachers lack the experience of the pure network teaching, and the teachers lack the confidence in the network teaching.

In view of this situation, teachers are trained to master the mode of network teaching, to promote the construction of network teaching depth, to broaden the means of teaching, and to inspire teachers to improve the level of network teaching. It is the general trend of higher education curriculum teaching to construct the school's own network teaching platform, realizing the network of teaching process, which has far-reaching influence on the education idea, teaching method, teaching content and teaching evaluation.

Taking the teachers of Nanchang Normal University as the research object, this paper uses the questionnaire star to send out questionnaires to ask for the teachers' online teaching situation. Through the feedback data of the platform, this study analyzes the actual effect of teachers' online teaching, understands the influence of various factors on the teaching effect, and puts forward targeted suggestions for these problems, so as to achieve the purpose of improving the teaching quality by using the network platform.

\section{Sample Data and Research Methods}

\subsection{Data Collection}

This study takes the teacher of Nanchang Normal University as the investigation object, uses the literature method and the questionnaire survey method to collect the sample data. The sample size can be determined according to the number of questions. Generally, the sample size is 5 times larger than the number of questions. 50 copies were distributed and 48 copies were recovered, the effective rate was $96 \%$. According to the data collected from questionnaires, the distribution of samples is relatively average in gender and subject category. Besides, $87.5 \%$ of respondents are under 45 years old. Table 1 shows the basic information of the survey sample, including gender, age, professional title and subject category.

\subsection{Research Method}

In this paper, qualitative analysis and quantitative analysis are combined to study the use of network teaching platform and teachers' network teaching situation, and Statistical Package for Social Sciences (named as SPSS) is used to ana- 
lyze the data obtained from the questionnaire [1] [2].

\section{Analysis of Online Teaching during Epidemic Period}

According to Table 2, the number of teachers participating in online course construction increased from $18(37.5 \%)$ to $27(56.25 \%)$, and online teaching increased from $18(37.5 \%)$ to $40(83.34 \%)$ before and during the epidemic. From the results, it can be seen that the proportion of teachers participating in online course construction or online teaching has been greatly increased. Teachers have to face the difficulties and force themselves to adapt to online teaching as soon as possible.

Table 1. Basic information of survey samples.

\begin{tabular}{|c|c|c|c|}
\hline Question & Item & Frequency & Percentage (\%) \\
\hline \multirow{2}{*}{ Gender } & Male & 28 & 58.3 \\
\hline & Female & 20 & 41.7 \\
\hline \multirow{4}{*}{ Age } & Under 35 & 18 & 37.5 \\
\hline & $36-45$ & 24 & 50.0 \\
\hline & $46-55$ & 5 & 10.4 \\
\hline & Over 56 & 1 & 2.1 \\
\hline \multirow{4}{*}{ Professional Title } & Professor & 4 & 8.3 \\
\hline & Associate Professor & 17 & 35.4 \\
\hline & Lecturer & 18 & 37.5 \\
\hline & Other & 9 & 18.8 \\
\hline \multirow{4}{*}{ Subject Category } & Literature & 7 & 14.6 \\
\hline & Physics & 14 & 29.2 \\
\hline & Engineering & 13 & 27.1 \\
\hline & Other & 14 & 29.2 \\
\hline Total & & 48 & 100.0 \\
\hline
\end{tabular}

Table 2. Participation in online course construction and online teaching before and during the epidemic.

\begin{tabular}{|c|c|c|c|c|}
\hline \multirow{2}{*}{ Item } & \multicolumn{2}{|c|}{ Before the epidemic } & \multicolumn{2}{|c|}{ During the epidemic } \\
\hline & Frequency & Percentage (\%) & Frequency & Percentage (\%) \\
\hline $\begin{array}{l}\text { Not involved in the construction of online courses } \\
\qquad \text { Not involved in online teaching }\end{array}$ & 21 & 43.75 & 7 & 14.58 \\
\hline $\begin{array}{l}\text { Not participated in the construction of online courses } \\
\qquad \& \text { Participated in online teaching }\end{array}$ & 9 & 18.75 & 14 & 29.17 \\
\hline $\begin{array}{l}\text { Participated in the construction of online courses } \\
\text { \& Not participated in online teaching }\end{array}$ & 9 & 18.75 & 1 & 2.08 \\
\hline $\begin{array}{l}\text { Participated in online course construction } \\
\text { \& Participated in online teaching }\end{array}$ & 9 & 18.75 & 26 & 54.17 \\
\hline & 48 & 100.0 & 48 & 100.0 \\
\hline
\end{tabular}


According to the paired sample t test, Table 3 shows the sample size, mean value and standard deviation before and during the epidemic. Table 4 shows the correlation coefficient of paired samples. Table 5 shows the paired sample test. It is found that the online course construction and online teaching is 2.13 before the epidemic and 2.96 during the epidemic, the online course construction and online teaching is improved by the epidemic. Before and during the epidemic situation, the $\mathrm{P}$ value of correlation is 0.004 , there is a significant relationship between before the epidemic and during the epidemic, the $t$ value of the paired $t$ test is $-4.463, \mathrm{P}=0.000<0.05$. Therefore, there are differences. It is considered that the differences between the online teaching activities of teachers before and during the epidemic are statistically significant, so it can be considered that the epidemic situation has a positive role in promoting teachers to carry out online teaching activities.

\section{Correlation Analysis of Teachers' Attitude, Teachers' Adaptability and Teaching Effect}

The correlation coefficient between teacher's attitude and teacher's adaptability (Table 6) is $0.846, \mathrm{P}=0.000<0.05$, and there is a high correlation; the correlation coefficient between teacher's attitude and teaching effect is $0.712, \mathrm{P}=0.000$ $<0.05$, and there is a strong correlation; the correlation coefficient between teacher's adaptability and teaching effect is $0.536, \mathrm{P}=0.000<0.05$, there is a medium correlation.

Table 3. Paired sample statistics.

\begin{tabular}{cccccc}
\hline & & Mean Value & $\mathrm{N}$ & $\begin{array}{c}\text { Standard } \\
\text { Deviation }\end{array}$ & $\begin{array}{c}\text { Standard error } \\
\text { of mean value }\end{array}$ \\
\hline \multirow{2}{*}{ Paired } & Before the epidemic & 2.13 & 48 & 1.178 & 0.170 \\
& During the epidemic & 2.96 & 48 & 1.202 & 0.174 \\
\hline
\end{tabular}

Table 4. Correlation coefficient of paired samples.

\begin{tabular}{ccccc}
\hline & & $\mathrm{N}$ & Correlation Coefficient & Sig. \\
\hline Paired & $\begin{array}{c}\text { Before the epidemic \& } \\
\text { During the epidemic }\end{array}$ & 48 & 0.409 & 0.004 \\
\hline
\end{tabular}

Table 5. Paired sample test.

\begin{tabular}{|c|c|c|c|c|c|c|c|c|c|}
\hline & & \multicolumn{5}{|c|}{ Paired Difference } & \multirow{3}{*}{$\mathrm{t}$} & \multirow{3}{*}{$\mathrm{df}$} & \multirow{3}{*}{$\begin{array}{c}\text { Sig. } \\
\text { (bilateral) }\end{array}$} \\
\hline & & \multirow{2}{*}{$\begin{array}{l}\text { Mean } \\
\text { Value }\end{array}$} & \multirow{2}{*}{$\begin{array}{l}\text { Standard } \\
\text { Deviation }\end{array}$} & \multirow{2}{*}{$\begin{array}{l}\text { Standard error } \\
\text { of mean value }\end{array}$} & \multicolumn{2}{|c|}{$\begin{array}{l}\text { 95\% confidence interval } \\
\text { of difference }\end{array}$} & & & \\
\hline & & & & & lower limit & upper limit & & & \\
\hline Paired & $\begin{array}{l}\text { Before the epidemic-During } \\
\text { the epidemic }\end{array}$ & -0.833 & 1.294 & 0.187 & -1.209 & -0.458 & -4.463 & 47 & 0.000 \\
\hline
\end{tabular}




\section{Regression Analysis}

According to Table 7, the independent variable is the teacher's attitude, and the dependent variable is the teaching effect, the input method is used for regression analysis. Table 8 is the summary of the model, $\mathrm{R}$ is the complex correlation coefficient, $\mathrm{R}=0.712$; $\mathrm{R}^{2}$ is used to reflect the explanatory degree of the model, $\mathrm{R}^{2}$ $=0.508$, that is, teachers' attitude can only explain $50.8 \%$ of the variation of teaching effect.

Table 9 shows the test results of model statistics using the analysis of variance, $\mathrm{F}=47.412, \mathrm{P}=0.000<0.05$. Therefore, the regression model is statistically significant. Table 10 shows the coefficients of the constructed model [3] [4], and the model

$$
\hat{y}=-0.009+1.048 x
$$

can be obtained. Where $x$ is the teacher's attitude, $\hat{y}$ is the predicted teaching effect. That is, every time the teacher's attitude is improved by 1 point, the teaching effect will also change and increase by 1.048 points.

Table 6. Correlation.

\begin{tabular}{|c|c|c|c|c|}
\hline & & $\begin{array}{c}\text { Teaching } \\
\text { effect }\end{array}$ & $\begin{array}{l}\text { Teachers' } \\
\text { attitude }\end{array}$ & $\begin{array}{c}\text { Teachers' } \\
\text { adaptability }\end{array}$ \\
\hline \multirow{3}{*}{$\begin{array}{c}\text { Teaching } \\
\text { effect }\end{array}$} & Pearson correlation & 1 & $0.712^{* *}$ & $0.536^{\star *}$ \\
\hline & Sig. (bilateral) & & 0.000 & 0.000 \\
\hline & $\mathrm{N}$ & 48 & 48 & 48 \\
\hline \multirow{3}{*}{$\begin{array}{l}\text { Teachers' } \\
\text { attitude }\end{array}$} & Pearson correlation & $0.712^{\star *}$ & 1 & $0.846^{\star *}$ \\
\hline & Sig. (bilateral) & 0.000 & & 0.000 \\
\hline & $\mathrm{N}$ & 48 & 48 & 48 \\
\hline \multirow{3}{*}{$\begin{array}{c}\text { Teachers' } \\
\text { adaptability }\end{array}$} & Pearson correlation & $0.536^{\star *}$ & $0.846^{* *}$ & 1 \\
\hline & Sig. (bilateral) & 0.000 & 0.000 & \\
\hline & $\mathrm{N}$ & 48 & 48 & 48 \\
\hline
\end{tabular}

${ }^{*}$ There is a significant correlation at 0.01 level (bilateral).

Table 7. Input/removed variable ${ }^{\mathrm{b}}$.

\begin{tabular}{|c|c|c|c|}
\hline Model & Input variable & Removed variable & Method \\
\hline 1 & Teachers' attitude ${ }^{a}$ & & input \\
\hline
\end{tabular}

${ }^{a}$ All requested variables have been entered; ${ }^{b}$ Dependent variable: teaching effect.

Table 8. Model summary.

\begin{tabular}{ccccc}
\hline Model & $\mathrm{R}$ & $\mathrm{R}^{2}$ & Adjust $\mathrm{R}^{2}$ & Error of standard estimation \\
\hline 1 & $0.712^{\mathrm{a}}$ & 0.508 & 0.497 & 0.581 \\
\hline
\end{tabular}

${ }^{a}$ Prediction variables: (constant), teachers' attitude. 
Table 9. Anova ${ }^{\mathrm{b}}$.

\begin{tabular}{ccccccc}
\hline \multicolumn{1}{l}{ Model } & Square sum & df & Mean square & F & Sig. \\
\hline & regression & 15.978 & 1 & 15.978 & 47.412 & $0.000^{\mathrm{a}}$ \\
1 & residual & 15.502 & 46 & 0.337 & & \\
& Total & 31.479 & 47 & & & \\
\hline
\end{tabular}

${ }^{a}$ Prediction variables: (constant), teachers' attitude; ${ }^{b}$ Dependent variable: teaching effect.

Table 10. Model coefficient $\mathrm{a}^{\mathrm{a}}$.

\begin{tabular}{|c|c|c|c|c|c|c|}
\hline & \multirow[t]{2}{*}{ Model } & \multicolumn{2}{|c|}{$\begin{array}{l}\text { Nonstandardization } \\
\text { coefficient }\end{array}$} & \multirow{2}{*}{$\begin{array}{c}\begin{array}{c}\text { Standardization } \\
\text { coefficient }\end{array} \\
\text { Trial version }\end{array}$} & \multirow[t]{2}{*}{$\mathrm{t}$} & \multirow[t]{2}{*}{ Sig. } \\
\hline & & B & Standard error & & & \\
\hline \multirow{2}{*}{1} & (constant) & -0.009 & 0.502 & & -0.018 & 0.985 \\
\hline & Teachers' attitude & 1.048 & 0.152 & 0.712 & 6.886 & 0.000 \\
\hline
\end{tabular}

${ }^{\mathrm{a} D e p e n d e n t ~ v a r i a b l e: ~ t e a c h i n g ~ e f f e c t . ~}$

\section{Conclusion}

This study describes the influencing factors of teaching effect, and also analyzes the correlation among teachers' adaptability, teachers' attitude and teaching effect. There is a positive correlation among teachers' adaptability, teachers' attitude and teaching effect. The prediction model of the relationship is constructed between teachers' attitude and teaching effect. In order to avoid unnecessary error, the sample size should be increased as much as possible, the paper mainly studies from teachers' teaching, and students' learning should also be included in the paper, so as to comprehensively study the effect of teaching and learning.

\section{Acknowledgements}

Project supported by the research on teaching reform of Nanchang Normal University (Grant No.JGKT-19-12), also by the research on science and technology of Nanchang Normal University (Grant No. 18KJYB05). The students' learning has become easier and more active; the teaching quality has been improved by it.

\section{Conflicts of Interest}

The author declares no conflicts of interest regarding the publication of this paper.

\section{References}

[1] Sun, S. and Zhou, M. (2019) Analysis of Farmers' Land Transfer Willingness and Satisfaction Based on SPSS Analysis of Computer Software. Cluster Computing: The Journal of Networks, Software Tools and Applications, 22, 9123-9131. https://doi.org/10.1007/s10586-018-2087-1

[2] Rao, R. (2018) Prominence and Application of SPSS for Social Science Research. In- 
ternational Journal of Trend in Scientific Research and Development, 2, 1471-1472. https://doi.org/10.31142/ijtsrd18870

[3] Qu, X., Qiu, M., Liu, J., Niu, Z. and Wu, X. (2019) Prediction of Maximal Water Bursting Discharge from Coal Seam Floor Based On Multiple Nonlinear Regression Analysis. Arabian Journal of Geosciences, 12, 1-20.

https://doi.org/10.1007/s12517-019-4748-7

[4] Chen, R. (2020) Analysis and Prediction of the Final Grade of Securities and Futures Based on SPSS. International Journal of Trend in Scientific Research and Development, 4, 394-396. 